\title{
Passive acoustic monitoring off Vancouver Island reveals extensive use by at-risk Resident killer whale (Orcinus orca) populations
}

\author{
Amalis Riera ${ }^{1, *}$, James F. Pilkington ${ }^{2}$, John K. B. Ford ${ }^{2}$, Eva H. Stredulinsky ${ }^{2}$, \\ N. Ross Chapman ${ }^{1}$ \\ ${ }^{1}$ University of Victoria, School of Earth and Ocean Sciences, Bob Wright Centre A405, 3800 Finnerty Rd, Victoria, \\ British Columbia V8P5C2, Canada \\ ${ }^{2}$ Pacific Biological Station, Fisheries and Oceans Canada, Nanaimo, British Columbia V9T 6N7, Canada
}

\begin{abstract}
Two sympatric populations of fish-eating Resident killer whales inhabit the coastal waters of British Columbia, Canada: Southern and Northern Resident killer whales. These populations are listed under Canada's Species at Risk Act (SARA) as 'endangered' and 'threatened', respectively. Relatively little is known about their habitat use outside of the sheltered waters along the east coast of Vancouver Island, especially during the winter. SARA requires the identification of critical habitat for these populations. High densities of Chinook salmon - their primary prey are found around Swiftsure Bank, an area identified as potential critical habitat for Southern Residents. However, it is a difficult area to survey for whales using conventional small-boat approaches. Here, we used $2 \mathrm{yr}$ of data collected from an autonomous acoustic recorder deployed at Swiftsure Bank from 2009-2011 to assess the year-round habitat use of this area by Resident killer whales. Overall, Resident killer whales were detected on 244 of 680 monitored days (36\%). Southern Residents were heard in all months, with activity peaking during the summer. Northern Residents were also heard throughout the year, but were mostly detected in the spring and fall, which indicates the 2 populations may differ in their strategies for using this common foraging area. High levels of use by both of these populations highlights the importance of Swiftsure Bank to both, supporting the expansion of Resident killer whale critical habitat to include this site.
\end{abstract}

KEY WORDS: Killer whales $\cdot$ Resident $\cdot$ Critical habitat $\cdot$ Passive acoustic monitoring

\section{INTRODUCTION}

Determining patterns in cetacean habitat use is challenging. Cetaceans are highly mobile, often occurring over expansive ranges in which their movements are generally difficult to predict (Mate et al. 1997, Wells et al. 1999, Isojunno et al. 2012). This challenge is amplified for rarely observed or cryptic species (Rayment et al. 2011). Data on habitat use, such as seasonal distribution and movement patterns, can be used to address fundamental questions that are important for conservation management of at-risk populations (Williams \& Thomas 2009,

\footnotetext{
${ }^{*}$ Corresponding author: ariera@uvic.ca
}

Embling et al. 2010, Santora \& Brown 2010, Becker et al. 2012). These fundamental questions include identification of critical habitat (Schorr et al. 2009, Williams et al. 2009, Baird et al. 2012), estimation of seasonal variability in diet (Anderwald et al. 2012), evaluation of the influence of environmental factors (Marubini et al. 2009, Dalla Rosa et al. 2012), assessment of anthropogenic threats (Mate et al. 1997), and identification of association patterns, such as habitat sharing and interactions between sympatric populations (Parra 2006, Baird et al. 2010).

Two discrete populations of fish-eating Resident killer whales are found in coastal British Columbia

(C) A. Riera, N. R. Chapman and Fisheries and Oceans Canada 2019. Open Access under Creative Commons by Attribution Licence. Use, distribution and reproduction are unrestricted. Authors and original publication must be credited. 
(BC), Canada, and adjacent waters of the USA and are partially sympatric, but do not mix or associate with one another. Both are listed under Canada's Species at Risk Act (SARA): Northern Residents as threatened (302-307 animals in 2017, DFO (Fisheries and Oceans Canada) Cetacean Research Program unpubl. data), and Southern Residents as endangered (76 animals in 2017, Center for Whale Research unpubl. data) (Fisheries and Oceans Canada 2011). These SARA listings require that the populations' critical habitat(s) be identified (Fisheries and Oceans Canada 2011). 'Critical habitat' is defined under the SARA as 'the habitat that is necessary for the survival or recovery of a listed wildlife species' (Fisheries and Oceans Canada 2011). Basic requirements for killer whale habitat have been identified as adequate availability of high-quality prey, freedom of movement, and an acoustic environment that allows for successful communication and foraging (Fisheries and Oceans Canada 2011). In particular, critical habitat for Resident killer whales should be situated in areas with high densities of their primary prey, close to topographic features that promote prey concentration, and in areas of steep bathymetry, well-mixed water, and strong tidal currents (Ford 2006).

Located southwest of Vancouver Island just west of the entrance to Juan De Fuca Strait, Swiftsure Bank is a highly productive area where deep ocean currents rise to the surface, providing nutrients to a rich and diverse ecosystem (McFarlane et al. 1997, Burger 2003). Recreational and commercial fishing are frequent in the area (Thomson et al. 1992), which is particularly productive for salmonids, especially Chinook salmon (Healey 1986, Healey et al. 1990), the preferred prey of both Resident populations (Ford et al. 1998, Ford \& Ellis 2006, Hanson et al. 2010). Resident killer whales have been encountered on Swiftsure Bank despite relatively little survey effort (DFO Northern and Southern Resident killer whale encounter databases 2013; B. Wright pers. comm.), suggesting the area could be an important feeding ground for them. Swiftsure Bank was therefore identified as a potentially important area that warranted further study. The open waters of Swiftsure Bank are generally not conducive to conventional study techniques using small boats due to remoteness and poor weather and sea conditions. However, autonomous acoustic instruments can be deployed at remote locations and record over extended periods to investigate killer whale presence across seasons and years (Yurk et al. 2010) while providing the additional benefits of being non-invasive (Nystuen et al. 2010) and monitoring regardless of the weather and time of day (Akamatsu et al. 2008, Giorli et al. 2015).

Three distinct lineages, or ecotypes, of killer whales are found in coastal waters of the northeastern Pacific (Ford et al. 2000). Despite sympatric distributions, each differs genetically, morphologically, behaviourally, ecologically, and acoustically. In addition to the salmon-feeding Residents, there are mammal-hunting Transients (Bigg's killer whales; Ford et al. 1998) and fish-eating Offshores (which may specialize in shark predation; Dahlheim et al. 2008, Ford et al. 2011, 2014). Each of these ecotypes can be reliably distinguished acoustically through distinctive vocalizations (Ford 1991, Deecke et al. 2005, Ford et al. 2014), an attribute that makes killer whales wellsuited for passive acoustic monitoring (PAM) techniques. More so, within the Resident ecotype, different populations (e.g. Northern and Southern Residents, Southern Alaskan Residents; Yurk et al. 2002) can also be reliably identified, as can smaller matrilineal groupings (e.g. clans and pods), by means of group-specific repertoires of stereotyped calls, or dialects (Ford 1991). An acoustic 'clan' is a group of pods with related dialects. Call repertoires of different clans have no overlapping call types (Ford 1989). The Northern Resident population is composed of 3 clans - A, G, and R - while the Southern Resident population consists of a single clan-J. In this study, we investigated the frequency of use and seasonal occurrence of Resident killer whales at Swiftsure Bank off the coast of BC, using long-term PAM.

\section{MATERIALS AND METHODS}

\subsection{Field methods}

Acoustic recordings were collected at Swiftsure Bank $\left(48^{\circ} 31^{\prime} \mathrm{N}, 124^{\circ} 56^{\prime} \mathrm{W}\right)$, off the southwest coast of Vancouver Island, BC, Canada (Fig. 1) from August 2009 until July 2011 using an AURAL-M2 (Autonomous Underwater Recorder for Acoustic Listening-Model 2; Multi Électronique), outfitted with an HTI-96-MIN (High Tech) hydrophone. Data collection involved 4 consecutive deployments, details of which are found in Table 1. For each deployment, the AURAL was moored at $72 \mathrm{~m}$ depth, suspended vertically $10 \mathrm{~m}$ above the bottom using subsurface flotation. The instrument recorded at a sampling frequency of $16.384 \mathrm{kHz}$, on a one-third duty cycle (Table 1). The first deployment used a $10 \mathrm{~min}$ on/ 5 min off duty cycle, but for the purposes of being 


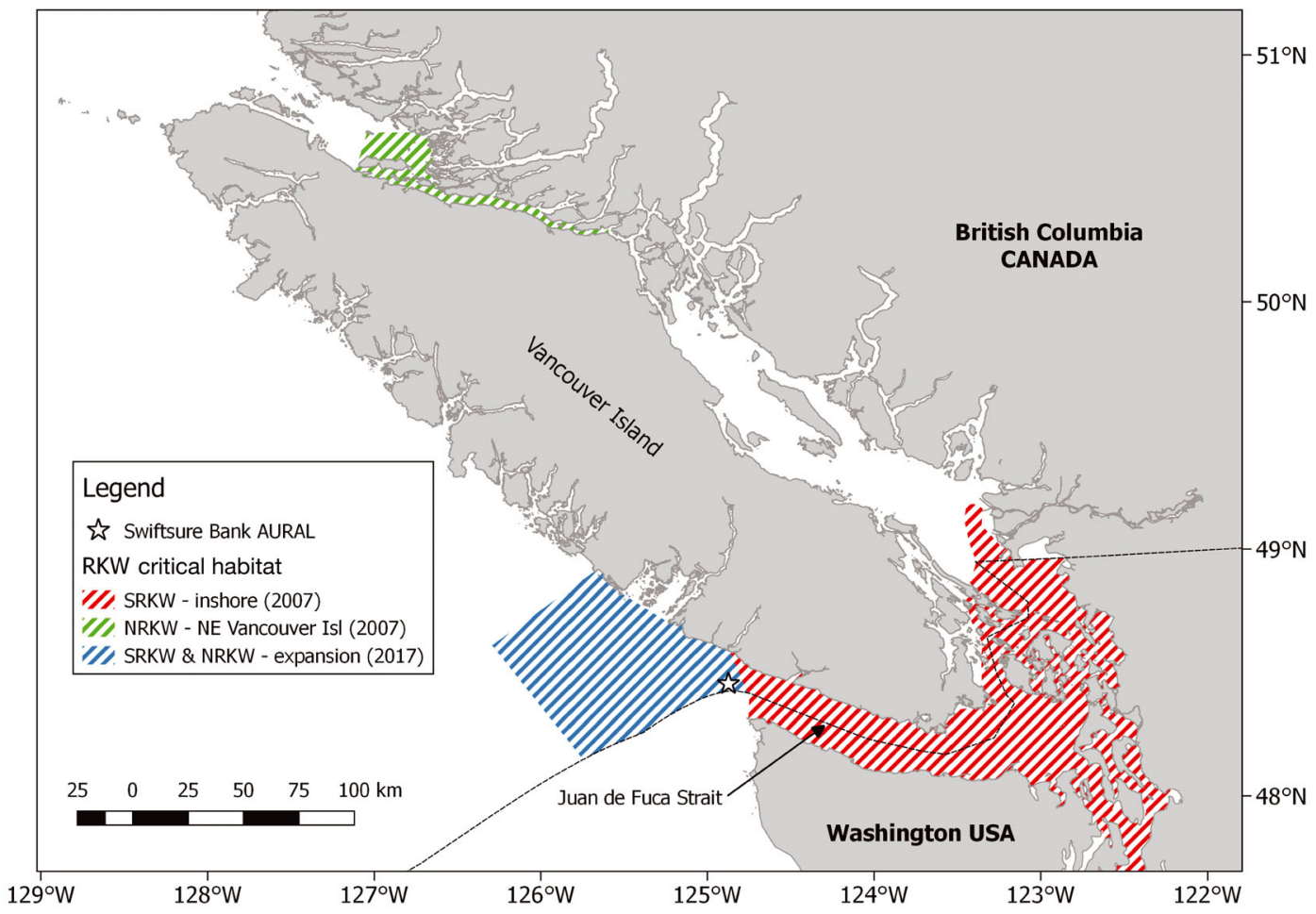

Fig. 1. Swiftsure Bank study site off the coast of British Columbia, Canada. Hashed lines: inshore critical habitats for Southern Resident (SRKW) and Northern Resident (NRKW) killer whales (designated in 2007) as well as the 2017 expansion of Southern and Northern Resident critical habitat

Table 1. Deployment information for acoustic data collection at Swiftsure Bank (August 2009-July 2011)

\begin{tabular}{|lccccc|}
\hline $\begin{array}{l}\text { Deployment } \\
\text { no. }\end{array}$ & $\begin{array}{c}\text { Date start } \\
\text { (yyyy-mm-dd) }\end{array}$ & $\begin{array}{c}\text { Date end } \\
\text { (yyyy-mm-dd) }\end{array}$ & $\begin{array}{c}\text { Cycle duration } \\
\text { (min) }\end{array}$ & $\begin{array}{c}\text { Duration of } \\
\text { recordings (min) }\end{array}$ & $\begin{array}{c}\text { Time between } \\
\text { recordings (min) }\end{array}$ \\
\hline 1 & $2009-07-23$ & $2009-09-23$ & 30 & 10 & 20 \\
2 & $2009-09-23$ & $2010-05-01$ & 30 & 9 & 21 \\
3 & $2010-05-01$ & $2010-03-26$ & 30 & 9 & 21 \\
4 & $2010-03-26$ & $2011-07-31$ & 15 & 4.5 & 10.5 \\
\hline
\end{tabular}

consistent with the analysis throughout the 2 yr we only analysed every other recording of this deployment's data set, which converted the duty cycle to 10 min on/20 min off. The duration of acoustic samples for the $2^{\text {nd }}$ and $3^{\text {rd }}$ deployments was shortened by 1 min to increase the total samples that could be stored on the AURAL's hard disk and lengthen the deployment duration. The duty cycle was also altered for the final deployment by shortening the recordings and making them more frequent. This reduced the gap period between recordings but maintained the same overall sampling ( one-third) and increased the likelihood of capturing short vocal bouts that could otherwise easily begin and end within a 20/21 min gap period. Vocal bouts defined by very frequent and sustained vocal activity were still captured. Earlier than predicted battery depletion in the final deployment caused a 50 d gap from 26 March-15 May 2011.

\subsection{Analytical methods}

Acoustic data were analysed in search of killer whale vocalizations following the methodology described in Riera et al. (2013) and Ford et al. (2017). The data were grouped into two 12 mo groups: August 2009-July 2010 (365 d) and August 2010-July 2011 (315 d). Recordings corresponding to the first year were all inspected manually, which 
involved visualizing every second of data as a spectrogram using TRITON (Wiggins \& Hildebrand 2007), a MATLAB (Mathworks) application. To speed up the analysis, recordings from the second year were processed with the SONS application (Laboratori d'Aplicacions Bioacústiques), an automated detector which we used to identify a subset of recordings most likely to contain killer whale vocalizations to be inspected in detail. The SONS application divided the data into $16 \mathrm{~s}$ segments and then calculated the probability that each segment contained a short-tonal signal, which could be a killer whale call. SONS has a MATLAB-based graphical user interface (GUI) for inspecting each $16 \mathrm{~s}$ segment of recording with an overlay plot of the detector-computed probability of a killer whale tonal being in that $16 \mathrm{~s}$ sample of the original audio file. The GUI allowed the analyst to view a spectrogram of the samples but not listen to them or change the spectrogram settings. When the brief spectrogram clips in the SONS GUI were not enough to confidently identify the species or killer whale group, the original audio file that encompassed the $16 \mathrm{~s}$ segment in question was reviewed using TRITON in its entirety.

To test the SONS detector's accuracy and choose a threshold that balanced positive and missed detections, we ran the detector on the first year of data, which had already been manually analysed. We defined 3 test data sets from SONS for evaluation against the manual results. The 3 data sets consisted of recordings containing at least one $16 \mathrm{~s}$ segment with a threshold of greater than or equal to 20,30 , or $40 \%$, respectively. The positive detection rate was calculated as the percentage of killer whale-containing recordings from the manually verified data set that were accounted for in the SONS-derived data set. The missed detection rate was calculated as the percentage of killer whale-containing recordings from the manually verified data set that were not accounted for in the SONS-derived data set. A threshold probability of 20 provided the highest positive detection rate ( $83 \%$ ) and the lowest missed detection rate $(17 \%)$, as opposed to $61 \%$ positive and $39 \%$ missed with a threshold of 30 and $42 \%$ positive and $58 \%$ missed with a threshold of 40 . Therefore, any recording containing a segment with a threshold of 20 or over was chosen for further visual and acoustic inspection.

When detected, killer whale calls were identified to the highest possible resolution of species, population, and group identity using a reference catalogue (Ford 1987) and a digitized visual and aural catalogue of call types (Cetacean Research Program, Pacific Bio- logical Station unpubl. data). Numerous detections had insufficient signal-to-noise ratios for identification beyond the species level. Calls of sufficient quality were first identified to ecotype-Resident, Transient, or Offshore. Resident vocalizations were further identified to population (Northern or Southern) and acoustic clan. Southern Resident vocalizations were further identified to the acoustic pod level when possible. Identification of pods within Northern Resident clans was not attempted for this study. The number of days with killer whales heard (of each population) was recorded.

Next, identified calls were organized into acoustic encounters. Encounters were considered to be periods in which the same group of killer whales (as determined by group-specific call types) was heard over consecutive recordings separated by less than $3 \mathrm{~h}$ without calls, as defined in Riera et al. (2013). Finally, the encounter duration (time that passes between the beginning of the first and end of the last recording in an acoustic encounter) was calculated in order to estimate the amount of time each group of whales spent in the vicinity of the recorder. When calls from a given killer whale group were detected and continued being heard after midnight they were considered to occur on 2 different days even though they belonged to the same encounter (this occurred 13 times for Southern Residents and 4 times for Northern Residents). The count of days with killer whales heard did not change the encounter duration, i.e. one encounter could include calls heard over 2 consecutive days.

The monthly median encounter duration was calculated by grouping all the encounter durations corresponding to each month, arranging the values from lowest to highest, and finding the value that was in the middle of the set for each month. For months with an even number of durations, the median was obtained by calculating the average of the 2 values in the middle. Encounters from the same month in different years of the study were grouped together.

The total time with calls per month was calculated by summing the durations of all encounters of a given group in each month.

\subsection{Estimation of killer whale detection ranges}

The area over which Resident killer whales could potentially be detected on the Swiftsure recorder was estimated for 4 months: January, June, July, and September. These months were chosen to represent detectability during periods with high (June and 
July), moderate (September), and low (January) numbers of detections. We modelled transmission loss along 32 radials centered at this site using the BELLHOP ray-tracing model (Porter 2011) available in the Effects of Sound on the Marine Environment (ESME) 2012 Workbench framework software (D. Mountain, Curtin University). For each of the $45 \mathrm{~km}$ long radials, ESME used built-in environmental databases from the Oceanographic and Atmospheric Master Library (OAML) to acquire location-specific bathymetry (at 0.5 min resolution; Digital Bathymetry Database v.5.4), sound speed profiles (at $15 \mathrm{~min}$ resolution; Generalized Digital Environment Model v.3.0.), bottom sediment composition (at 5 min resolution; Bottom Sediment Type v.2.0), and surface reflectivity (at 60 min resolution; Surface Marine Gridded Climatology v.2.0) for each of the months in question. To model the propagation of a source that was representative of a killer whale call, we used a call source level of $152 \mathrm{~dB}$ re $1 \mu \mathrm{Pa} @ 1 \mathrm{~m}$, which is the average source level for discrete calls produced by Northern Residents (Miller 2006) and is also within the variability of source levels presented for Southern Resident calls by Holt et al. (2011). We also specified call frequency of $1200 \mathrm{~Hz}$ and duration of $1 \mathrm{~s}$, representative of the 'N05' call type produced commonly by Northern Residents (but also bares similarity to several Southern Resident calls and call components; Ford 1987). To define a representative calling depth, we averaged all dive depths from digital acoustic recording tag (DTAG) data available from a previous study of Northern Resident foraging behaviour (Wright et al. 2017), resulting in an average dive depth of $7 \mathrm{~m}$ across all behaviour types. Assuming that most calling behaviour occurs around the depth at which killer whales spend most of their time, we used $10 \mathrm{~m}$ as the representative calling depth, which was the closest depth bin in the transmission loss outputs. The detection distance along each radial was then determined as the distance at which the transmission loss at $10 \mathrm{~m}$ depth fell below the maximum allowable transmission loss (MaxTL), defined in Širović et al. (2015) as:

$$
\operatorname{MaxTL}=\mathrm{SL}-\mathrm{NL}-D
$$

where SL is the call source level, NL is the ambient noise level, and $D$ is the detectability of the signal. We chose to define detectability of a $1200 \mathrm{~Hz}$ sound by a listening analyst as $5 \mathrm{~dB}$.

NL in the $1 \mathrm{~Hz}$ bands surrounding $1200 \mathrm{~Hz}$ was calculated for the respective months over the $2 \mathrm{yr}$ of data at Swiftsure (September 2009-2010, January, June, and July 2010-2011). Power spectral densities
(PSDs) were computed with $15 \mathrm{~s}$ time averaging (Welch 1967) in $1 \mathrm{~Hz}$ bins (with a $1 \mathrm{~s}$ window, $50 \%$ overlap) using the recorder and hydrophone manufacturers' technical specifications and user-defined recorder gain settings. The PSDs were computed in R v.3.0.0 (R Core Team 2018) using the software PAMGuide (Merchant et al. 2015). Prior to noise measurement, all periods in the PSD that overlapped with killer whale acoustic encounters were removed to exclude noise produced by killer whales in the measurements. The noise level (in units of $\mathrm{dB}$ re $1 \mathrm{\mu Pa}^{2}$ ) for each month was then computed by integrating the spectral density over the 1199, 1200, and $1201 \mathrm{~Hz}$ bins.

Custom R scripts were used to calculate the position of maximum detection range along each radial in decimal degrees of latitude and longitude. For each month, these points were then connected to form a spatial polygon representing the detection area around the hydrophone location. We calculated the area (in $\mathrm{km}^{2}$ ) of each month's detection polygon according to Bevis \& Cambareri (1987) using the 'areaPolygon' function in the $\mathrm{R}$ package 'rgeos' (Bivand et al. 2016). The polygons were then mapped using QGIS v.3.0.0 (QGIS Development Team 2018). Bathymetry data for the figures were downloaded from Smith \& Sandwell (1997).

\section{RESULTS}

From 1 August 2009-31 July 2011, Resident killer whales were detected on a total of $244 \mathrm{~d}$ at Swiftsure Bank (Figs. 2 \& 3): Southern Residents on 163 d ( $24 \%$ of recorded days), and Northern Residents on $95 \mathrm{~d}$ (14\% of recorded days). There were $14 \mathrm{~d}$ in which both populations were heard on the same day. Considering the data gap of $50 \mathrm{~d}$ between 26 March and 15 May 2011, a total of $680 \mathrm{~d}$ were monitored during this study, and Resident killer whales were detected on $36 \%$ of those days.

Seasonally, both Southern and Northern Resident calls were found throughout the year (Figs. $2 \& 3$ ); however, Southern Residents were predominantly detected in summer and Northern Resident calls predominantly in spring and fall.

\subsection{Duration of acoustic encounters}

Over the 2 yr study period, there were 175 Southern Resident encounters for a cumulative duration of $594.3 \mathrm{~h}$, and 118 Northern Resident encounters for a 


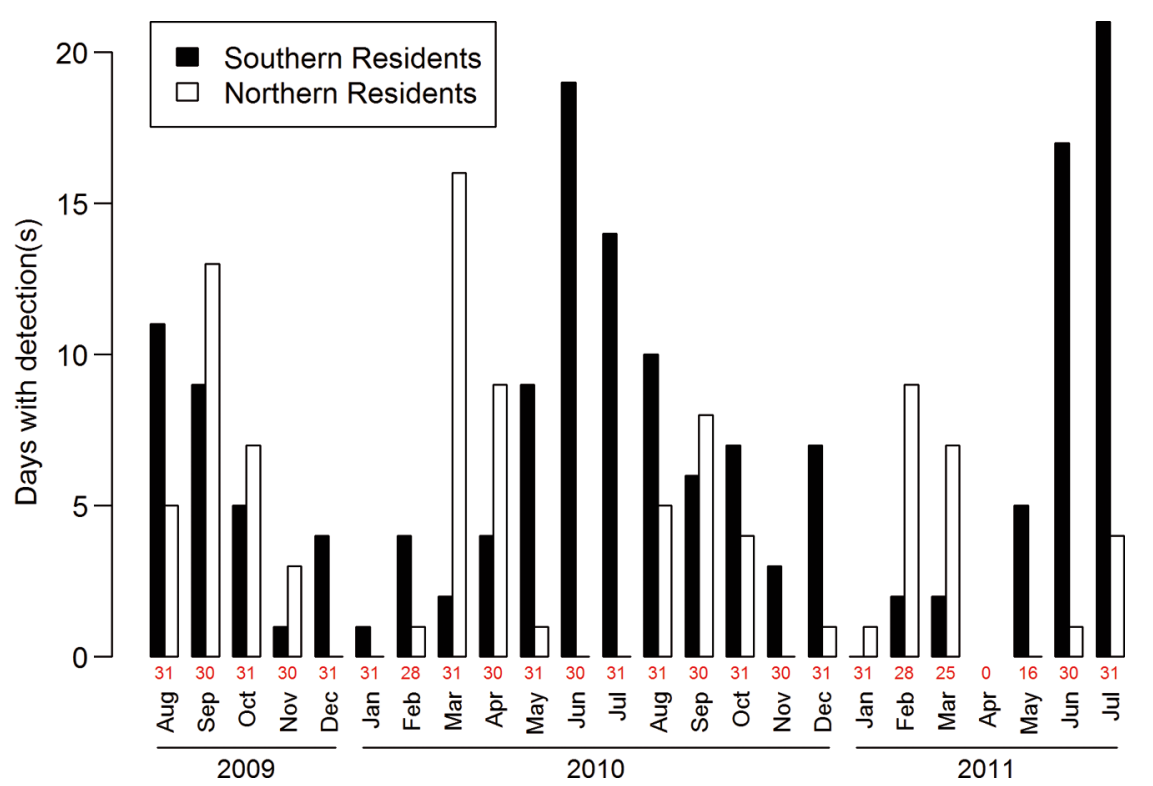

Fig. 2. Number of days with acoustic detection(s) at Swiftsure Bank for Southern $(\mathrm{n}=163 \mathrm{~d})$ and Northern $(\mathrm{n}=$ 95 d) Resident killer whales during each month of the time series (August 2009July 2011). Numbers in red: days of effort. No data were available for $50 \mathrm{~d}$ between 26 March and 15 May 2011 cumulative duration of $418.8 \mathrm{~h}$. The number of encounters varied seasonally for both populations (Fig. 4). The majority of Southern Resident encounters $(75 \%)$ were found in summer (May-September) and most Northern Resident encounters $(79 \%)$ took place in fall (September-October) and spring (February-April, even despite the lack of data for April 2011). Similarly, the total time with calls $\mathrm{mo}^{-1}$ was greater in May-August $(76 \%$ of total time with calls within the 2 yr study period) for Southern Residents and in March-April and August-October (83\% of total time with calls) for Northern Residents.

The monthly median encounter duration for Southern Residents ranged between 0.2 and $5.2 \mathrm{~h}$. It was greater than $1 \mathrm{~h}$ (between 1.2 and $5.2 \mathrm{~h}$ ) for the majority of the year $(10 \mathrm{mo})$ and more than $2 \mathrm{~h}$ (from

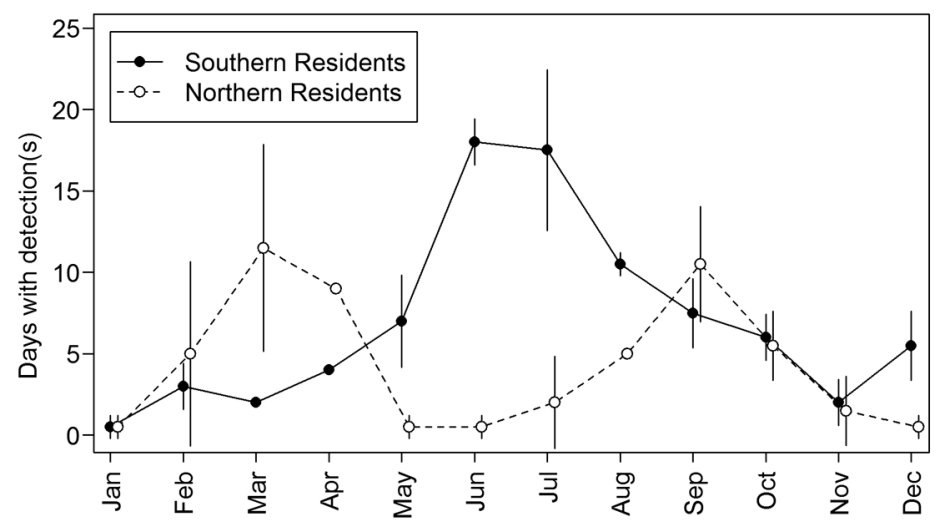

Fig. 3. Average $( \pm \mathrm{SD})$ number of detection-days of Southern and Northern Resident killer whales in each month. All months had 2 yr of data analysed, except April, which only had 1 yr analysed (2010)
2.7 to $5.2 \mathrm{~h}$ ) for half of the year (6 mo). Encounter durations ranged from one single acoustic sample ( 0.1 or $0.2 \mathrm{~h}$, depending on the duty cycle, which happened in $21 \%$ of encounters) to as long as $21 \mathrm{~h}$ (May 2010) and were longer than $2 \mathrm{~h}$ for $54 \%$ of encounters. For Northern Residents, monthly median encounter durations ranged between 1.7 and $7.7 \mathrm{~h}$, and were greater than $2 \mathrm{~h}$ for most of the year $(10 \mathrm{mo})$. Encounter durations varied from 0.1 or $0.2 \mathrm{~h}$ (in $23 \%$ of encounters) to $16 \mathrm{~h}$ (March 2010), and were longer than $2 \mathrm{~h}$ for $58 \%$ of encounters. The monthly median encounter duration was lowest in November and January for Southern Residents and OctoberDecember for Northern Residents.

All 3 Southern Resident pods were detected at least once during each month of the year, except J pod in January and November, and L pod in March (Fig. 5). Some encounters included more than one pod together. $\mathrm{K}$ and $\mathrm{L}$ pods were heard more often in the summer (87 and $89 \%$ of total time with $\mathrm{K}$ and L calls, respectively, occurred between May and September), whereas J pod was more present in winter and spring $(76 \%$ of total time with J calls was accounted for by activity in December, February, March, April, and May). L and K pods were heard over the longest periods of time in the summer (for example, median encounter duration for L pod in May was $5.7 \mathrm{~h}$, and median encounter duration for $\mathrm{K}$ pod in June was $4.7 \mathrm{~h}$ ). The longest encounter durations for $\mathrm{J}$ pod occurred during the winter (for example, the median encounter duration was $6.7 \mathrm{~h}$ in February and $5.7 \mathrm{~h}$ in December). Of all 
Fig. 4. Encounter duration on Swiftsure Bank, for Southern $(n=175)$ and Northern ( $\mathrm{n}=118)$ Resident killer whales from August 2009-July 2011. This represents the amount of time each individual pod was heard on site, regardless of whether they were heard alone or together with other pods (thus there may be duplicate encounters). Boxplots display encounter duration-boxes: upper and lower quartiles (where $50 \%$ of values fall); horizontal line: median; whiskers: maximum and minimum values; dots: outliers. Isolated horizontal lines indicate no variability in values (i.e. only a single encounter occurred in that month or all encounters for that month had the same duration). Top panel: total number of encounters (enc.) group $^{-1} \mathrm{mo}^{-1}$

Fig. 5. Southern Resident killer whale encounter duration at Swiftsure Bank, for J ( $\mathrm{n}=40), \mathrm{K}(\mathrm{n}=105)$, and $\mathrm{L}(\mathrm{n}=71)$ pods from August 2009-July 2011. Encounters for each pod were considered independently; therefore encounters with more than one pod present are represented multiple times. Top panel: total number of encounters (enc.) group ${ }^{-1}$ and $\mathrm{mo}^{-1}$. Box plots as in Fig. 4
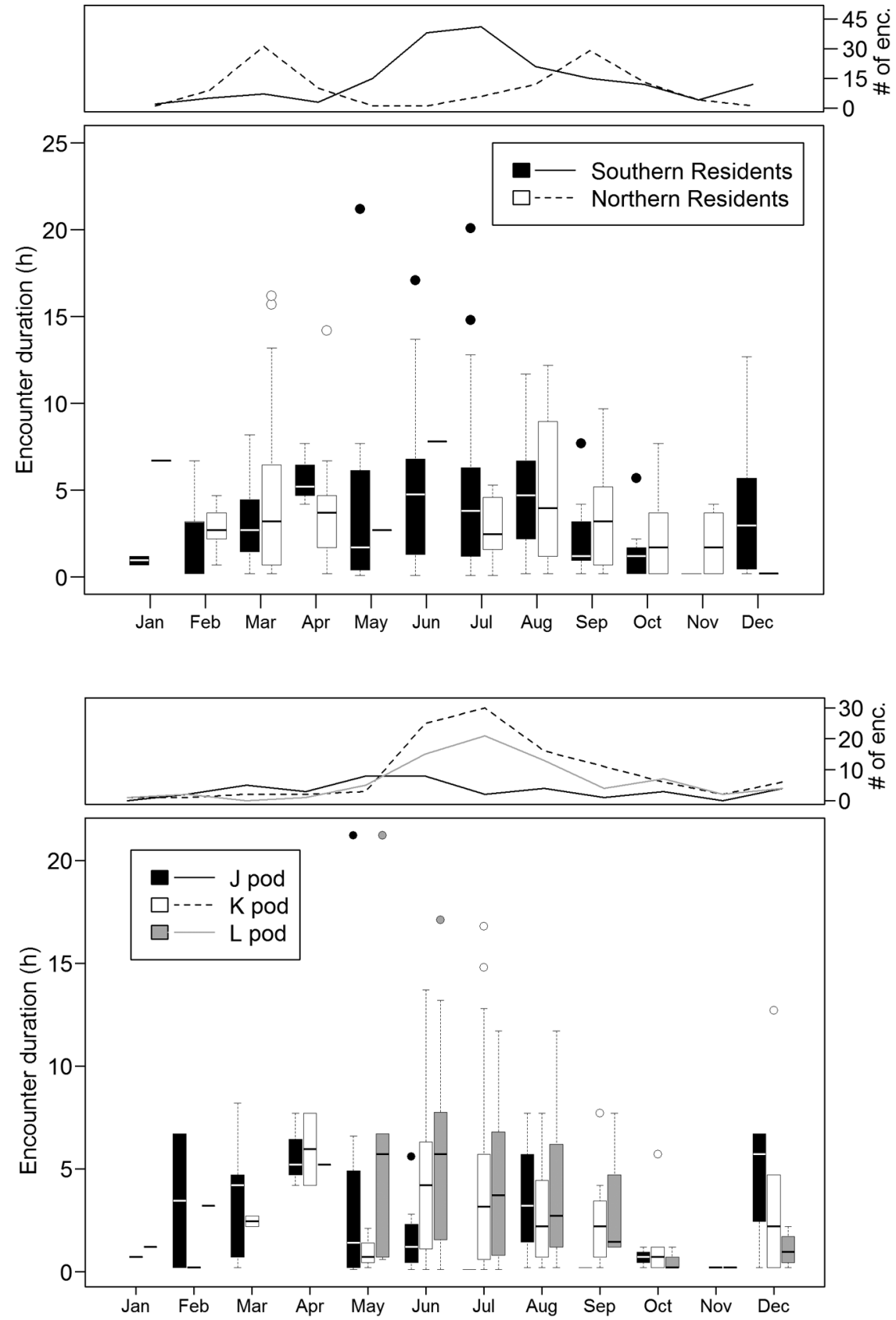

$\mathrm{K}$ pod encounters that were longer than $2 \mathrm{~h}, 87 \%$ occurred between June and September. The proportion of $\mathrm{L}$ pod encounters longer than $2 \mathrm{~h}$ that occurred in the summer was $79 \%$. For J pod, $72 \%$ of encounters that were longer than $2 \mathrm{~h}$ occurred between December and May.

The presence of Northern Residents in Swiftsure Bank was almost exclusively represented by G clan with 114 encounters, 12 A clan encounters and only 2 short detections of R clan (Fig. 6).
The median encounter duration for $G$ clan was greater than $1.7 \mathrm{~h}$ in all months except December, while the months with most encounters (89\%) and longest total time with calls (91\%) were FebruaryApril and August-October. There were 5 A clan encounters that were longer than $2 \mathrm{~h}$, one of which lasted $7.7 \mathrm{~h}$ in October 2009. The rest of encounters were under $1 \mathrm{~h}$. Most A clan detections occurred between July and October, except 2 encounters in March 2010. 


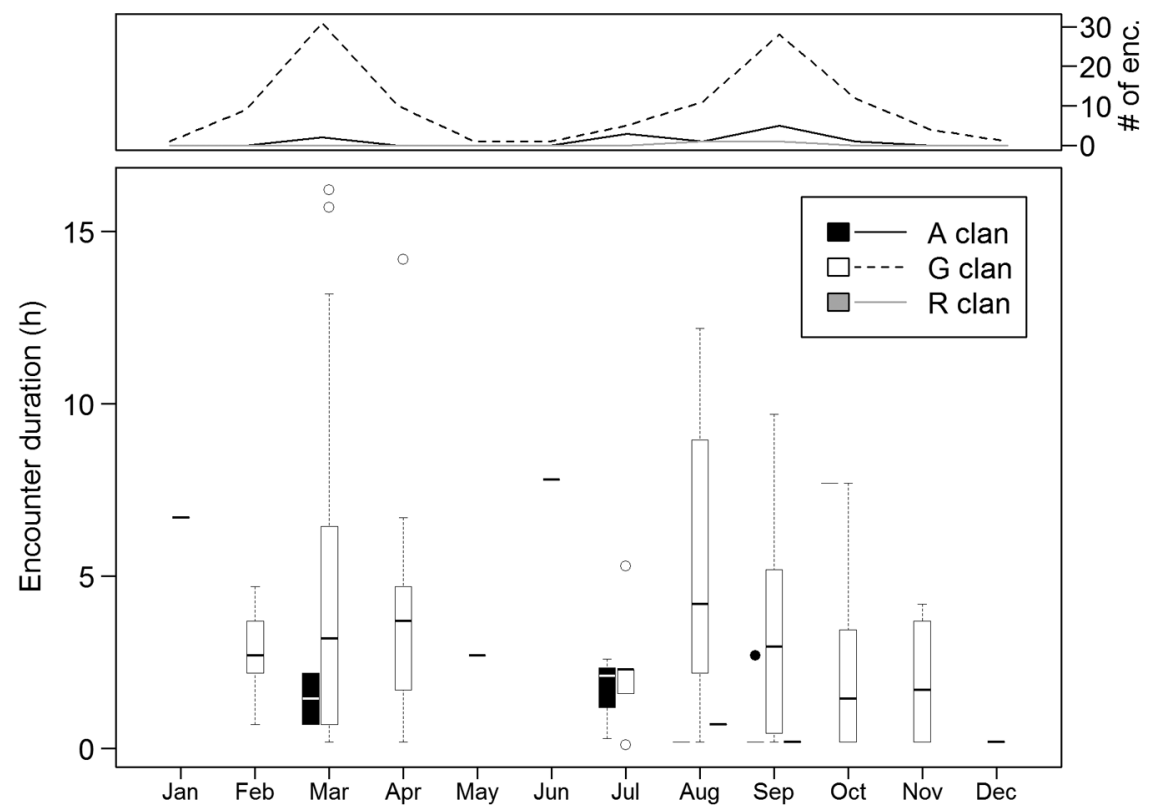

Fig. 6. Northern Resident killer whale encounter duration at Swiftsure Bank, for $A(n=12), G(n=114)$, and $R(n=2)$ clans from August 2009-July 2011 . Encounters for each clan were considered independently; therefore encounters with more than one pod present are represented multiple times. Top panel: total number of encounters (enc.) group ${ }^{-1}$ and $\mathrm{mo}^{-1}$. Box plots as in

Fig. 4

\subsection{Detection range modelling}

The distances from which killer whale vocalizations could potentially be detected at this recorder site were modelled using average site-specific ambient noise and environmental conditions for 4 representative months. The modelled calls were detectable to a maximum of $8.8 \mathrm{~km}$ (one radial in

Table 2. Monthly estimated killer whale detection distances based on Bellhop transmission loss modelling. For each month, 36 distance estimates were calculated $\left(1 \mathrm{radial}^{-1}\right)$. Mean detection distance is the average of the 36 distance estimates in the given month. Minimum and maximum detection distances refer to the smallest and largest of the 36 distance estimates in the given month. The detection area is computed as the area of the polygon created by joining the location of the estimated detection distance for each of the 36 radials in the given month (see Fig. 7)

\begin{tabular}{|lccc|}
\hline Month & $\begin{array}{c}\text { Mean detection } \\
\text { distance }(\mathrm{km})\end{array}$ & $\begin{array}{c}\text { Min./max. } \\
\text { detection } \\
\text { distance }(\mathrm{km})\end{array}$ & $\begin{array}{c}\text { Detection } \\
\text { area }\left(\mathrm{km}^{2}\right)\end{array}$ \\
\hline January & 5.0 & $3.46 / 7.2$ & 83 \\
June & 5.8 & $4.8 / 7.9$ & 105 \\
July & 6.0 & $4.6 / 8.8$ & 115 \\
September & 6.5 & $5.1 / 8.6$ & 135 \\
\hline
\end{tabular}

July) and a minimum of $3.3 \mathrm{~km}$ (one radial in January). A summary of the modelled detection distances for each month is provided in Table 2 . The total area of each month's detection polygon was $83 \mathrm{~km}^{2}$ (January), $105 \mathrm{~km}^{2}$ (June), $115 \mathrm{~km}^{2}$ (July), and $135 \mathrm{~km}^{2}$ (September). These polygons are presented in Fig. 7.

\section{DISCUSSION}

Resident killer whales were detected on over one-third $(36 \%)$ of the days monitored throughout this study. Although previous evidence from visual sightings in the area suggested Southern Residents would be regularly detected at this site (Calambokidis et al. 2004, Ford 2006, Ford et al. 2007, DFO Northern and Southern Resident killer whale encounter databases 2013; B. Wright pers. comm.), the frequent detections of Northern Residents was less expected. The fact that Northern Resident detections occurred predominantly during the late fall and late winter months, periods with very little boat-based effort due to poor conditions, highlights the immense benefit of using PAM for assessing the year-round frequency of habitat use for these populations. However, it is also important to note the limitations of PAM within the context of this study. Data was collected using a onethird duty-cycle, which means the recorder was not active for two-thirds of the total time over the study period. Also, non-focal noise sources can occasionally mask killer whale calls, such as other species (e.g. humpback whale, pacific white-sided dolphin), vessels (i.e. the recorder was located within the shipping lanes of one of the busiest marine shipping routes in the world), and natural abiotic sources (i.e. noise from wind, rain, snow, and waves). Additionally, the use of an automated detector with a 'missed detection' rate of $17 \%$ suggests that recordings with killer whales were missed for the $2^{\text {nd }}$ year of data. Finally, PAM methods can only detect killer whales when they are vocalizing and when conditions allow those vocalizations to be received at the hydrophone. These factors mean that the frequency of occurrence for these populations presented in this study represent the absolute minimum levels of presence over the study time period. 


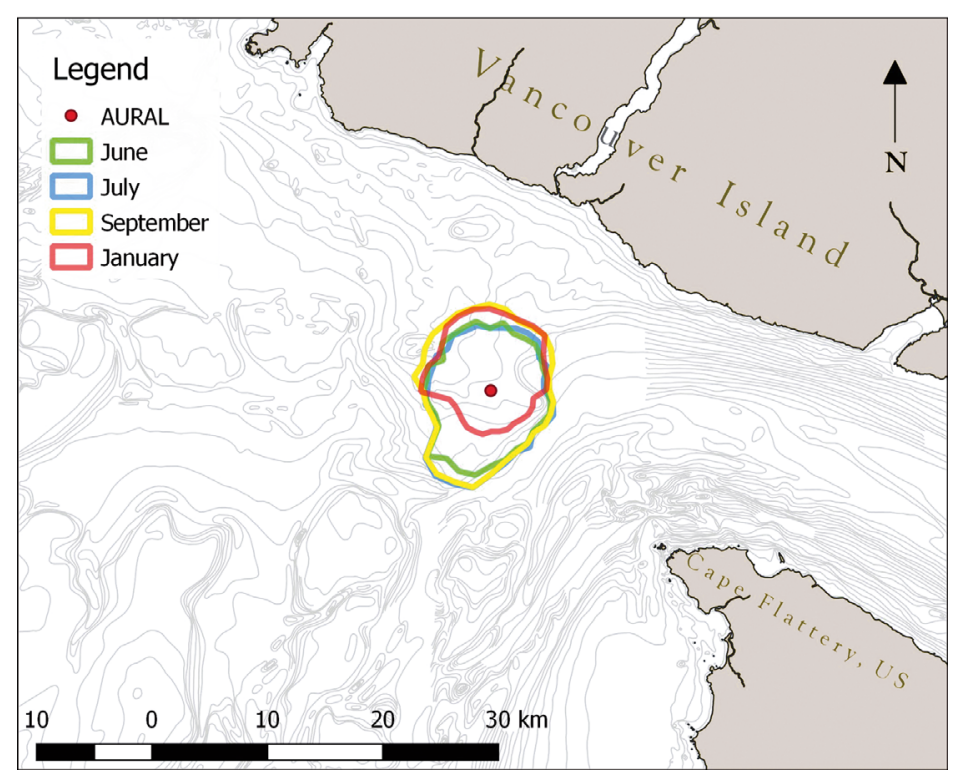

Fig. 7. Estimated areas of detectability of Resident killer whale calls based on propagation modelling exercise under average conditions at the Swiftsure Bank recorder (AURAL) site, for selected months, 2009-2011

Not only do these results improve our understanding of the overall use of the Swiftsure Bank area by these 2 populations, they also improve our understanding of the seasonal use of the area. Southern Residents were present in most months of both years and especially in summer. This supports Ford's (2006) hypothesis that when Southern Resident killer whales are absent from the inner portions of their protected inshore critical habitat area in summer, they spend most of that time in western Juan de Fuca Strait or areas off the southwest coast of Vancouver Island around Swiftsure Bank. The results show that Southern Residents were present at Swiftsure Bank on 121 d between May and September in 2009-2011, which corresponds to $40 \%$ of total summer days.

Encounter durations were chosen as indicators of habitat use because they add weight to the seasonal patterns shown by the number of days with detections per month. However, uncertainty arises when trying to infer behaviour from encounter duration. Brief encounters could indicate that a group of whales simply transited through the study site. On the other hand, a brief encounter would also result from a very short vocal bout during a quiet behavioural state like resting (Ford 1989), even though the animals could remain in the detection range for hours at a time while resting. Longer encounter durations could result from a variety of vocalizing behaviour, including frequent and sustained vocalizing or infrequent vocalization bouts interspersed with gaps of up to $3 \mathrm{~h}$; both situations would indicate that the whales are using the habitat for a wider range of behaviours, including foraging and socializing. The encounter durations reported here were often prolonged, suggesting that the whales were making use of the habitat rather than simply transiting through it.

Despite frequently associating, each Southern Resident pod has a different pattern of occurrence throughout their range (Ford 2006, Hauser et al. 2007, Hanson et al. 2010, 2013, Olson et al. 2018), so the seasonal variability in pod occurrence observed in our study was not unexpected. J pod was the least frequently detected at Swiftsure Bank. Although infrequently detected, most J pod encounters occurred in winter and spring and were detected as often or more often than $\mathrm{K}$ and $\mathrm{L}$ pods during these seasons. J pod was present in relatively few acoustic encounters at Swiftsure during the summer months, a period dominated by $\mathrm{K}$ and $\mathrm{L}$ pods. These results are consistent with other studies (Ford 2006, Hauser et al. 2007, Hanson et al. 2010, 2013, Fisheries and Oceans Canada 2011, Olson et al. 2018). Ford (2006) reported that K and L pods make regular trips to areas off the western entrance of Juan de Fuca Strait and the west coast of Vancouver Island between June and September, which is supported by the high number of encounters and their average duration found in our study. Likewise, our study shows that $\mathrm{J}$ pod also undertakes these trips out of Juan de Fuca in summer, but far less frequently than do $\mathrm{K}$ and $\mathrm{L}$ pods. The number of encounters of each pod from November to April was substantially lower than during the summer months. However, at least one Southern Resident encounter occurred during each winter month, and the monthly median encounter duration for $\mathrm{J}$ and $\mathrm{L}$ pods during this period was high. In fact, J pod monthly median encounter durations were generally longer during the winter than in the summertime (Fig. 5). Also, previous studies have shown that $\mathrm{K}$ and L pods are typically absent from their usual summertime areas during December-May (Ford 2006), and seem to make use of outer coast areas like Swiftsure (as in the present study) and waters from Washington down to California (Hanson et al. 2013, Rice et al. 2017). Although monitoring at all of these outer coast sites during the winter months has resulted in relatively low rates of encounter compared to summertime encounter rates in critical habitat, taken collectively this suggests that Southern Residents range widely 
in the winter and rely on the shelf waters of this outer coast region in its entirety in the wintertime.

Northern Residents are most commonly sighted off the coast of northeastern Vancouver Island and the northern mainland coast of $\mathrm{BC}$, especially during July-October (Ford 2006). They have occasionally been sighted as far south as Gray's Harbor, Washington, but sightings off the west coast of Vancouver Island are uncommon. Interestingly, after combining the Swiftsure Bank detections over the $2 \mathrm{yr}$ study period, Northern Residents were detected in all months of the year. This Resident population was almost exclusively represented at Swiftsure Bank by G clan, with only $10 \%$ of encounters $(n=118)$ being from A clan and $2 \%$ from $\mathrm{R}$ clan. These results support previous work suggesting different parts of the Northern Resident population favour the use of certain geographic areas of the population's overall range (Fisheries and Oceans Canada 2011), and also highlight the high seasonal presence of G clan off the southwest coast of Vancouver Island. Average encounter duration was high in most months, indicating prolonged use of the area rather than transiting through. Similar to Southern Residents, it could be that Northern Residents are exploiting early Chinook runs that appear in the area as the fish migrate towards their natal rivers. Southern Residents have been detected near the mouth of the Columbia River between January and May, and also around Cape Elizabeth, just north of the Columbia River, between January and June (Rice et al. 2017), timing that coincides with the return of spring Chinook to the Columbia River (Hanson et al. 2013). Also, juvenile Chinook salmon can be found off the west coast of Vancouver Island during all seasons (Tucker et al. 2012), suggesting they may find adequate conditions and food supply in highly productive areas such as Swiftsure Bank and exploit these locations during the winter as adults.

Resident killer whale diet studies have concentrated most of their effort in the summer. Although prey samples that have been collected and identified in the winter are also predominantly Chinook salmon, chum salmon are also preyed upon frequently, predominantly in the fall months (Ford et al. 2010). Diet studies outside of established critical habitat have also reported a strong preference for Chinook salmon as well as frequent fall predation on chum for both Resident killer whale populations (Ford et al. 2010, 2017). Chinook salmon preyed upon by Resident killer whales have been identified as belonging to 19 regional spawning populations or stocks (Ford et al. 2010). The majority of Chinook captured near the en- trance to Juan de Fuca Strait originate from the Fraser River system, although there are also stocks from Puget Sound and the west coast of Vancouver Island (Hanson et al. 2010). Chinook salmon may return to their natal river to spawn during almost any month of the year but there are typically 1-3 peaks of migratory activity or runs (Groot \& Margolis 1991). For Fraser River Chinook, there are 3 main runs: spring (late June-early July), summer (late July-early August), and fall (early August-late September), during which these fish are common in Southern Residents' critical habitat (Hanson et al. 2010). Situated at the west entrance to Juan de Fuca Strait, a geographic bottleneck for salmon returning to the Fraser River and Puget Sound via the west coast of Vancouver Island, Swiftsure Bank sees a peak of salmon abundance prior to their appearance in the whales' critical habitat (Ayres et al. 2012). This could explain the increase in detections of Residents in May, June, and July on our Swiftsure Bank recorder. For instance, the longest encounter duration for Southern Residents in this study was $21 \mathrm{~h}$, and it occurred in May 2010, followed by 17 h in July 2011.

Although the number of Southern Resident encounters decreased substantially from November through April, the monthly median encounter duration remained above $1 \mathrm{~h}$ (except for November), being as high as $5 \mathrm{~h}$ in December, March, and April during the 2009-2010 period, even though the estimated wintertime detection area at this site was smaller than summer months. Despite the decrease in frequency of visits, the duration of visits, when they occur, suggests that the whales do not just transit through the area during winter. The monthly median encounter duration was lower during the 2010-2011 winter than the previous year. The number of detections during March, April, and May 2011 are likely underestimations due to the lack of data for $50 \mathrm{~d}$ during these $3 \mathrm{mo}$.

We undertook detection range modelling in order to determine whether seasonal differences in killer whale detections could be explained by seasonal propagation effects, and also to determine the average area of potential detectability around the hydrophone site to provide spatial context to the study results. The modelled ranges were often shorter than numerically derived detection ranges calculated for the same location in Riera et al. (2013) $(\sim 9 \mathrm{~km}$, in Beaufort Sea State 2). As the ranges in the current study took into account actual monthly average ambient noise conditions at the site and range-dependent environmental variables, our results may be more representative of the average detection ranges around the hydrophone site than the previous numerically derived estimates. 
This study's results are also consistent with Miller's (2006) active space predictions for killer whale discrete calls for noise conditions between Sea State 2 and 6 , in water depths of $100 \mathrm{~m}$. The modelling results suggest that under average conditions in most months the Swiftsure recorder detection area covered the majority of Swiftsure Bank, but overall, was a very small area relative to the waters available to the whales off southwest Vancouver Island. Detection areas for the 4 mo modelled did not vary greatly, but January had the most reduced detection area of the months tested, and also had the fewest number of days with Resident killer whale detections of any month in the study. Although it is possible that a reduced detection area could have resulted in fewer detections during this month as opposed to true absence, propagation distance only comprises one part of detectability. Behaviour is also a key component of detectability; for example, variations in vocalization rates/types differ based on behavioural state (Ford 1989). There is also anecdotal evidence that Resident killer whale calling behaviour may be reduced in winter versus summer, but this has yet to be assessed. Notably, Northern Residents were detected relatively frequently in later winter months compared to Southern Residents, implying that detection range may not have been the only factor leading to the dirth of detections of Southern Residents over the same time period.

Interestingly, differing patterns in the seasonality of Southern and Northern Resident presence at Swiftsure Bank indicate that temporal habitat partitioning among the 2 populations may occur. Rice et al. (2017) also highlighted this possibility from $7 \mathrm{yr}$ of acoustic monitoring off the outer coast of Washington, however had very few encounters with Northern Residents from which to draw conclusions. At Swiftsure Bank, our results show there were far more Northern Resident encounters than Southern Resident encounters during spring and fall (especially September and March), surrounding the peak Southern Resident usage in summer (Fig. 4). Both of these periods counted with expected high abundance of Chinook around Swiftsure Bank. Several cetacean species exhibit temporal variability in habitat use to avoid interspecific competition for limited resources (Perrin et al. 1985, Gowans \& Whitehead 1995, Bearzi 2005, Azzellino et al. 2008, Simon et al. 2010, Nichol et al. 2013). Sequential habitat use has also been reported for sympatric populations of Resident killer whales in Alaska (Yurk et al. 2010). These observations support the idea that the 2 Resident populations in our study could be temporally partitioning their use of the Swiftsure Bank region to avoid food com- petition; however, other factors, such as the littleunderstood social dynamics between the 2 populations, could also be playing a role.

The results reported here document for the first time a year-round presence of Resident killer whales on Swiftsure Bank, highlighting particular patterns of occurrence for each population. The monitoring effort in our study was constant throughout the year, unlike previous studies (Ford 2006, Hauser et al. 2007, Hanson et al. 2010) where the numbers of days of effort during the winter were few to non-existent (with the exception of the study by Hanson et al. 2013, which provided no effort outside of winter and spring months). During a 6 yr study period, Hauser et al. (2007) found Southern Residents on an average of $79 \%$ of days between May and September in their previously identified inshore critical habitat area (Fig. 1). Here, we detected Southern Residents at Swiftsure Bank on $42 \%$ of days between May and September over 2 yr. The proportion of days with detections in this study is lower than that reported by Hauser et al. (2007). However, Hauser et al. (2007) obtained their sightings data using an extensive network of commercial whale-watchers throughout an area of over $3000 \mathrm{~km}^{2}$, whereas our data were collected from a single hydrophone location with a predicted detection area that ranged from just $82.7 \mathrm{~km}^{2}$ (January) to $135.1 \mathrm{~km}^{2}$ (September). We suggest that, given the differences in effort, the occurrence of Southern Residents during the summer at Swiftsure Bank could indicate that the importance of this locations is at levels similar to many locations within their previously designated inshore critical habitat (Fig. 1).

The numerous detections and the long durations of encounters documented at Swiftsure Bank in this study suggest that the area is an important habitat for both Southern and Northern Residents. These results partially support the expansion of Southern and Northern Residents' critical habitat to include the Swiftsure Bank region, as proposed in Ford et al. (2017).

Given the relatively few previous killer whale sightings in the study area, these new data highlight the effectiveness of using PAM to provide information relevant to the seasonal occurrence of killer whales. Our results improve the current understanding of the temporal distribution patterns of different killer whale populations and contribute information that could be helpful to fulfill conservation requirements for this species, such as supporting further critical habitat designations, making it an important contribution to the future conservation and management of at-risk killer whale populations. 
Acknowledgements. We thank John Hildebrand and Sean Wiggins for providing the software, TRITON, that was used in this study and for their help in providing training on using the software and tools. We thank Michel André from Universitat Politècnica de Catalunya for providing the SONS algorithm. We are also grateful to Robin Abernethy for maintaining the recorders for these deployments, extracting the sound files from the AURALs and handling the data before analysis. We would also like to acknowledge Canadian Coast Guard crew members of the 'John P. Tully', as well as Tamas Juhasz and colleagues of the Institute of Ocean Sciences for conducting the deployment and recovery of the AURAL recorders on Swiftsure Bank. This study was supported by Obra Social La Caixa and the International Council for Canadian Studies and the Species at Risk Program of Fisheries and Oceans Canada.

\section{LITERATURE CITED}

Akamatsu T, Nakazawa I, Tsuchiyama T, Kimura N (2008) Evidence of nighttime movement of finless porpoises through Kanmon Strait monitored using a stationary acoustic recording device. Fish Sci 74:970-975

Anderwald P, Evans PGH, Dyer R, Dale A, Wright PJ, Hoelzel AR (2012) Spatial scale and environmental determinants in minke whale habitat use and foraging. Mar Ecol Prog Ser 450:259-274

Ayres KL, Booth RK, Hempelmann JA, Koski KL and others (2012) Distinguishing the impacts of inadequate prey and vessel traffic on an endangered killer whale (Orcinus orca) population. PLOS ONE 7:e36842

Azzellino A, Gaspari S, Airoldi S, Nani B (2008) Habitat use and preferences of cetaceans along the continental slope and the adjacent pelagic waters in the western Ligurian Sea. Deep Sea Res I 55:296-323

Baird RW, Schorr GS, Webster DL, McSweeney DJ, Hanson MB, Andrews RD (2010) Movements and habitat use of satellite-tagged false killer whales around the main Hawaiian Islands. Endang Species Res 10:107-121

Baird RW, Hanson MB, Schorr GS, Webster DL and others (2012) Range and primary habitats of Hawaiian insular false killer whales: informing determination of critical habitat. Endang Species Res 18:47-61

Bearzi M (2005) Dolphin sympatric ecology. Mar Biol Res 1: 165-175

* Becker EA, Foley DG, Forney KA, Barlow J, Redfern JV, Gentemann CL (2012) Forecasting cetacean abundance patterns to enhance management decisions. Endang Species Res 16:97-112

Bevis M, Cambareri G (1987) Computing the area of a spherical polygon of arbitrary shape. Math Geol 19:335-346

Bivand R, Rundel C, Pebesma E, Hufthammer KO (2016) rgeos: interface to geometry engine-open source ('GEOS'). R package version 03-25. https://cran.rproject.org/web/packages/rgeos/index.html

Burger AE (2003) Effects of the Juan de Fuca eddy and upwelling on densities and distributions of seabirds off southwest Vancouver Island, British Columbia. Mar Ornithol 31:113-122

Calambokidis J, Steiger GH, Ellifrit DK, Troutman BL, Bowlby CE (2004) Distribution and abundance of humpback whales (Megaptera novaeangliae) and other marine mammals off the northern Washington coast. Fish Bull 102:563-580
Dahlheim ME, Schulman-Janiger A, Black N, Ternullo R, Ellifrit D, Balcomb KC (2008) Eastern temperate North Pacific offshore killer whales (Orcinus orca): occurrence, movements, and insights into feeding ecology. Mar Mamm Sci 24:719-729

Dalla Rosa L, Ford JKB, Trites AW (2012) Distribution and relative abundance of humpback whales in relation to environmental variables in coastal British Columbia and adjacent waters. Cont Shelf Res 36:89-104

* Deecke VB, Ford JKB, Slater PJB (2005) The vocal behaviour of mammal-eating killer whales: communicating with costly calls. Anim Behav 69:395-405

*Embling CB, Gillibrand PA, Gordon J, Shrimpton J, Stevick PT, Hammond PS (2010) Using habitat models to identify suitable sites for marine protected areas for harbour porpoises (Phocoena phocoena). Biol Conserv 143:267-279

Fisheries and Oceans Canada (2011) Recovery strategy for the Northern and Southern Resident killer whales (Orcinus orca) in Canada. Species Risk Act Recovery Strategy Series. Fisheries \& Oceans Canada, Ottawa

Ford JKB (1987) A catalogue of underwater calls produced by killer whales (Orcinus orca) in British Columbia. Can Data Rep Fish Aquat Sci 633:1-165

Ford JKB (1989) Acoustic behaviour of resident killer whales (Orcinus orca) off Vancouver Island, British Columbia. Can J Zool 67:727-745

* Ford JKB (1991) Vocal traditions among resident killer whales (Orcinus orca) in coastal waters of British Columbia. Can J Zool 69:1454-1483

Ford JKB (2006) An assessment of critical habitats of resident killer whales in waters off the Pacific coast of Canada. DFO Can Sci Advis Sec Res Doc 2006/072

Ford JKB, Ellis GM (2006) Selective foraging by fish-eating killer whales Orcinus orca in British Columbia. Mar Ecol Prog Ser 316:185-199

Ford JKB, Ellis GM, Barrett-Lennard LG, Morton AB, Palm RS, Balcomb KC III (1998) Dietary specialization in two sympatric populations of killer whales (Orcinus orca) in coastal British Columbia and adjacent waters. Can J Zool 76:1456-1471

Ford JKB, Ellis G, Balcomb KC (2000) Killer whales: the natural history and genealogy of Orcinus orca in British Columbia and Washington, $2^{\text {nd }}$ edn. University of British Columbia Press, Vancouver

Ford JKB, Ellis G, Durban J (2007) An assessment of the potential for recovery of West Coast Transient killer whales using coastal waters of British Columbia. DFO Can Sci Advis Sec Res Doc 2007/088

Ford JKB, Wright BM, Ellis GM, Candy JR (2010) Chinook salmon predation by resident killer whales: seasonal and regional selectivity, stock identity of prey, and consumption rates. DFO Can Sci Advis Sec Res Doc 2009/101

F Ford JKB, Ellis GM, Matkin CO, Wetklo MH, BarrettLennard LG, Withler RE (2011) Shark predation and tooth wear in a population of northeastern Pacific killer whales. Aquat Biol 11:213-224

Ford JKB, Stredulinsky EH, Ellis GM, Durban JW, Pilkington JF (2014) Offshore killer whales in Canadian Pacific waters: distribution, seasonality, foraging ecology, population status and potential for recovery. DFO Can Sci Advis Sec Res Doc 2014/088

Ford JK, Pilkington JF, Riera A, Otsuki M and others (2017) Habitats of special importance to Resident killer whales (Orcinus orca) off the west coast of Canada. DFO Can Sci Advis Sec Res Doc 2017/035 
Giorli G, Au WWL, Ou H, Jarvis S, Morrissey R, Moretti D (2015) Acoustic detection of biosonar activity of deep diving odontocetes at Josephine Seamount High Seas Marine Protected Area. J Acoust Soc Am 137:2495-2501

Gowans S, Whitehead H (1995) Distribution and habitat partitioning by small odontocetes in the Gully, a submarine canyon on the Scotian Shelf. Can J Zool 73:1599-1608

Groot C, Margolis L (1991) Pacific salmon life histories. University of British Columbia Press, Vancouver

Hanson MB, Baird RW, Ford JKB, Hempelmann-Halos J and others (2010) Species and stock identification of prey consumed by endangered southern resident killer whales in their summer range. Endang Species Res 11: 69-82

Hanson MB, Emmons CK, Ward EJ, Nystuen JA, Lammers MO (2013) Assessing the coastal occurrence of endangered killer whales using autonomous passive acoustic recorders. J Acoust Soc Am 134:3486-3495

Hauser DDW, Logsdon MG, Holmes EE, VanBlaricom GR, Osborne RW (2007) Summer distribution patterns of southern resident killer whales Orcinus orca: core areas and spatial segregation of social groups. Mar Ecol Prog Ser 351:301-310

Healey MC (1986) Regional and seasonal attributes of catch in the British Columbia troll fishery. Can Tech Rep Fish Aquat Sci 1494:1-65

* Healey MC, Thomson RE, Morris JFT (1990) Distribution of commercial troll fishing vessels off southwest Vancouver Island in relation to fishing success and oceanic water properties and circulation. Can J Fish Aquat Sci 47: 1846-1864

Holt MM, Noren DP, Emmons CK (2011) Effects of noise levels and call types on the source levels of killer whale calls. J Acoust Soc Am 130:3100-3106

Isojunno S, Matthiopoulos J, Evans PGH (2012) Harbour porpoise habitat preferences: robust spatio-temporal inferences from opportunistic data. Mar Ecol Prog Ser 448:155-170

Marubini F, Gimona A, Evans PGH, Wright PJ, Pierce GJ (2009) Habitat preferences and interannual variability in occurrence of the harbour porpoise Phocoena phocoena off northwest Scotland. Mar Ecol Prog Ser 381:297-310

Mate BR, Nieukirk SL, Kraus SD (1997) Satellite-monitored movements of the northern right whale. J Wildl Manag 61:1393-1405

McFarlane GA, Ware DM, Thomson RE, Mackas DL, Robinson CLK (1997) Physical, biological and fisheries oceanography of a large ecosystem (west coast of Vancouver Island) and implications for management. Oceanol Acta 20:191-200

Merchant ND, Fristrup KM, Johnson MP, Tyack PL, Witt MJ, Blondel P, Parks SE (2015) Measuring acoustic habitats. Methods Ecol Evol 6:257-265

Miller PJO (2006) Diversity in sound pressure levels and estimated active space of resident killer whale vocalizations. J Comp Physiol A 192:449-459

Nichol LM, Hall AM, Ellis GM, Stredulinsky E, Boogaards M, Ford JKB (2013) Dietary overlap and niche partitioning of sympatric harbour porpoises and Dall's porpoises in the Salish Sea. Prog Oceanogr 115:202-210

* Nystuen JA, Moore SE, Stabeno PJ (2010) A sound budget for the southeastern Bering Sea: measuring wind, rainfall, shipping, and other sources of underwater sound. J Acoust Soc Am 128:58-65

* Olson JK, Wood J, Osborne RW, Barrett-Lennard L, Larson
S (2018) Sightings of southern resident killer whales in the Salish Sea 1976-2014: the importance of a long-term opportunistic dataset. Endang Species Res 37:105-118

*Parra GJ (2006) Resource partitioning in sympatric delphinids: space use and habitat preferences of Australian snubfin and Indo-Pacific humpback dolphins. J Anim Ecol 75:862-874

Perrin WF, Scott MD, Walker GJ, Cass VL (1985) Review of geographical stocks of tropical dolphins (Stenella spp. and Delphinus delphis) in the eastern Pacific. NOAA Tech Rep NMFS:1-28

Porter MB (2011) The bellhop manual and user's guide. Heat, Light, and Sound Research, La Jolla, CA

QGIS Development Team (2018) QGIS geographic information system version 3.0.0 'Girona'. Open Source Geospatial Foundation Project. http://qgis.osgeo.org

R Core Team (2018) R: a language and environment for statistical computing. R Foundation for Statistical Computing, Vienna

* Rayment W, Dawson S, Scali S, Slooten L (2011) Listening for a needle in a haystack: passive acoustic detection of dolphins at very low densities. Endang Species Res 14: 149-156

Kice A, Deecke V, Ford J, Pilkington J, Oleson E, Hildebrand J, Širović A (2017) Spatial and temporal occurrence of killer whale ecotypes off the outer coast of Washington State, USA. Mar Ecol Prog Ser 572:255-268

Riera A, Ford JK, Ross Chapman N (2013) Effects of different analysis techniques and recording duty cycles on passive acoustic monitoring of killer whales. J Acoust Soc Am 134:2393-2404

* Santora JA, Brown ET (2010) Spatial distribution patterns of southern bottlenose whales, Hyperoodon planifrons, near the South Shetland Islands, Antarctica. Mar Mamm Sci 26:960-968

* Schorr GS, Baird RW, Hanson MB, Webster DL, McSweeney DJ, Andrews RD (2009) Movements of satellite-tagged Blainville's beaked whales off the island of Hawai'i. Endang Species Res 10:203-213

* Simon M, Nuuttila H, Reyes-Zamudio MM, Ugarte F, Verfub U, Evans PGH (2010) Passive acoustic monitoring of bottlenose dolphin and harbour porpoise, in Cardigan Bay, Wales, with implications for habitat use and partitioning. J Mar Biol Assoc UK 90:1539-1545

* Širović A, Rice A, Chou E, Hildebrand J, Wiggins S, Roch M (2015) Seven years of blue and fin whale call abundance in the Southern California Bight. Endang Species Res 28: $61-76$

Smith WH, Sandwell DT (1997) Global sea floor topography from satellite altimetry and ship depth soundings. Science 277:1956-1962

Thomson RE, Healey MC, Morris JFT, Borstad GA (1992) Commercial troll fishing vessel distribution off Vancouver Island during July 1988: relation to observed physical oceanography. Can J Fish Aquat Sci 49:820-832

* Tucker S, Trudel M, Welch DW, Candy JR and others (2012) Annual coastal migration of juvenile Chinook salmon: static stock-specific patterns in a highly dynamic ocean. Mar Ecol Prog Ser 449:245-262

*Welch PD (1967) The use of fast Fourier transform for the estimation of power spectra: a method based on time averaging over short, modified periodograms. IEEE Trans Audio Electroacoust 15:70-73

*Wells RS, Rhinehart HL, Cunningham P, Whaley J, Baran M, Koberna C, Costa DP (1999) Long distance offshore 
movements of bottlenose dolphins. Mar Mamm Sci 15: 1098-1114

Wiggins SM, Hildebrand JA (2007) High-frequency acoustic recording package (HARP) for broad-band, long-term marine mammal monitoring. In: $5^{\text {th }}$ Int Symp Underwater Tech and $5^{\text {th }}$ Workshop on Scientific Use of Submarine Cables and Related Technologies. IEEE, Tokyo, p 551-557

Williams R, Thomas L (2009) Cost-effective abundance estimation of rare animals: testing performance of smallboat surveys for killer whales in British Columbia. Biol Conserv 142:1542-1547

Williams R, Lusseau D, Hammond PS (2009) The role of social aggregations and protected areas in killer whale conservation: the mixed blessing of critical habitat. Biol Conserv 142:709-719

Editorial responsibility: Ana Cañadas,

Durham, NC, USA
Wright BM, Ford JKB, Ellis GM, Deecke VB, Shapiro AD, Battaile BC, Trites AW (2017) Fine-scale foraging movements by fish-eating killer whales (Orcinus orca) relate to the vertical distributions and escape responses of salmonid prey (Oncorhynchus spp.). Mov Ecol 5:3

* Yurk H, Barrett-Lennard L, Ford JKB, Matkin CO (2002) Cultural transmission within maternal lineages: vocal clans in resident killer whales in southern Alaska. Anim Behav 63:1103-1119

* Yurk H, Filatova O, Matkin CO, Barrett-Lennard LG, Brittain $M$ (2010) Sequential habitat use by two resident killer whale (Orcinus orca) clans in Resurrection Bay, Alaska, as determined by remote acoustic monitoring. Aquat Mamm 36:67-78

Submitted: November 19, 2018; Accepted: May 4, 2019 Proofs received from author(s): July 5, 2019 